\title{
The Titration of Trachoma and Inclusion Blennorrhoea Viruses in Cell Gultures
}

\author{
By G. FURNESS, DORIS M. GRAHAM AND P. REEVE \\ Medical Research Council, Trachoma Research Unit, \\ The Lister Institute of Preventive Medicine, London, S.W. 1
}

(Received 27 June 1960)

\begin{abstract}
SUMMARY
A technique is described for titrating trachoma and inclusion blennorrhoea viruses by counting the inclusions formed in HeLa cell monolayers. The method compares favourably in accuracy with other techniques used for the assay of viruses and is more reliable than titration in the chick embryo yolk sac.
\end{abstract}

\section{INTRODUCTION}

Hitherto trachoma and inclusion blennorrhoea viruses have been titrated only by inoculating suitable dilutions of a virus suspension into the yolk sac of embryonated eggs and recording either the death or infection of the embryos. However, since chick embryos vary in susceptibility to these viruses, this method is not satisfactory. Sometimes, even after a large inoculum, infection of the egg cannot be demonstrated (Collier, Duke-Elder \& Jones, 1958). The finding that some strains of trachoma and inclusion blennorrhoea viruses induce cytoplasmic inclusions in cell cultures suggested an alternative method of titration (Furness, Graham, Reeve \& Collier, 1960). The present paper describes a technique for assaying these viruses by counting the cytoplasmic inclusions formed in monolayers of HeLa cells.

\section{METHODS}

Viruses. The TE 55 strain of trachoma virus (T'ang, Chang, Huang \& Wang, 1957) and the LBI strain of inclusion blennorrhoea virus (Jones, Collier \& Smith, 1959) were used.

HeLa cells. Stock cultures were propagated in $250 \mathrm{ml}$. bottles containing $10 \mathrm{ml}$. medium. The medium consisted of Hanks's balanced saline solution with the addition of $5 \%(\mathrm{v} / \mathrm{v})$ tryptic digest broth, $0.5 \%(\mathrm{w} / \mathrm{v})$ lactalbumin hydrolysate, $10 \%(\mathrm{v} / \mathrm{v})$ horse serum, $2 \%(\mathrm{v} / \mathrm{v})$ rabbit serum and $200 \mu \mathrm{g}$. streptomycin $/ \mathrm{ml}$.; adjusted to $\mathrm{pH} \mathbf{7 \cdot 2 - 7 \cdot 4}$ with $1 \cdot 4 \%(\mathrm{w} / \mathrm{v}) \mathrm{NaHCO}_{3}$. Serum was heated at $56^{\circ}$ for $30 \mathrm{~min}$.

When monolayers of HeLa cells had formed, they were washed in phosphatebuffered saline (PBS) without calcium or magnesium and separated by $3 \mathrm{ml}$. $0.02 \%(w / v)$ ethylenediamine tetra-acetic acid in PBS (Lwoff, Dulbecco, Vogt \& Lwoff, 1955). The cell suspension was diluted tenfold in medium and dispensed in $10 \mathrm{ml}$. amounts into bottles or $2 \mathrm{ml}$. amounts into Leighton tubes, each containing a coverslip (Bellco Glass Inc., Vineland, N.J., U.S.A.). The cultures were incubated at $37^{\circ}$. 
Virus assay. When the HeLa cells had formed a monolayer in the Leighton tubes, the medium was changed and each of four tubes was inoculated with 0.1 or $0.2 \mathrm{ml}$. of a suitable virus dilution. After incubation for $\mathbf{7 2} \mathrm{hr}$. the coverslips were removed, washed in buffer $\mathrm{pH} 6 \cdot 8$, fixed in $95 \%(\mathrm{v} / \mathrm{v})$ methanol in water for $1 \mathrm{hr}$. and stained with Giemsa May-Grünwald (8 ml. Giemsa; $4 \mathrm{ml}$. May-Grünwald; $80 \mathrm{ml}$. buffer, pH 6.8). The cells were differentiated for 60-90 min. in buffer, dried at $37^{\circ}$, cleared for $2 \mathrm{~min}$. in xylene and mounted in $\operatorname{DePeX}$ (G. T. Gurr and Co. Ltd.). The cells were examined at a magnification of $\times 240$ and the inclusions counted. Only vesicles containing stainable material and distorting the nucleus were accepted as virus inclusions.

Estimation of inclusion forming units (IFU). By means of a micrometer slide, the area of a microscopic field was estimated to be $0.196 \mathrm{~mm} . .^{2}$ at a magnification of $\times \mathbf{2 4 0}$. The Leighton tubes had a rectangular well with a base measuring $11 \times 39 \mathrm{~mm}$, an area of $429 \mathrm{~mm} .^{2}$ This was partly covered by a coverslip measuring $9 \times 38 \mathrm{~mm}$. The monolayer formed a continuous sheet of cells over both the coverslip and the exposed surface of the well not covered by the coverslip. Thus, the area of the monolayer exposed to infection with virus was equivalent to the surface area of the well of the Leighton tube, i.e. $429 \mathrm{~mm} .^{2}$ The number of fields in this area equals

$$
\frac{\text { total area of monolayer }}{\text { area of field }}=\frac{429}{0 \cdot 196} \text { or } c .2200 \text {. }
$$

Assuming random adsorption of the virus over the surface of the monolayer, the number of IFU/ml. is given by the formula

$$
\frac{\text { no. IFU counted }}{\text { no. of fields examined }} \times \mathbf{2 2 0 0 ,}
$$

adjusted by a factor determined by the volume and dilution of the inoculum.

Disruption of HeLa cells by ultrasonic vibrations. To disrupt the cells and release virus, the infected cells were scraped into the supernatant medium and transferred to a $50 \mathrm{ml}$. centrifuge tube cooled in ice water. The suspension was treated for $4 \mathrm{~min}$. with ultrasonic vibrations by inserting the probe of an M.S.E. Mullard ultrasonic disintegrator with a power output of $60 \mathrm{~W}$. at a frequency of $20 \mathrm{kc} / \mathrm{sec}$.

Partial purification of virus in yolk sacs. After homogenizing the infected yolk sac for $1 \mathrm{~min}$. in an M.S.E. blender with 4-5 ml. sucrose + potassium glutamate solution (Bovarnick, Miller \& Snyder, 1950), the suspension was clarified by centrifuging at $1500 \mathrm{rev} . / \mathrm{min}$. for $10 \mathrm{~min}$. The supernatant fluid was then centrifuged at $10,000 \mathrm{~g}$ for $90 \mathrm{~min}$. in an angle head at $4^{\circ}$ to deposit the virus which was finally resuspended in 4-5 ml. sucrose + potassium glutamate solution.

\section{RESULTS}

Infection of cells. Monolayers of HeLa cells in bottles were inoculated with $1 \mathrm{ml}$. purified infected yolk-sac suspension. After incubation for 6-18 hr. the medium was changed and the cells re-incubated. Both viruses produced some inclusions within 3-5 days. After 6-7 days the cells were resuspended in fresh medium and used to inoculate further monolayers. After about three serial passages, almost all the cells contained inclusions; these heavily infected cultures were used in these experiments. 
Preparation of virus suspensions. Preliminary observations indicated that not all the virus was released spontaneously from the inclusions. The use of ultrasonic vibrations (USV) and freezing and thawing as a means of releasing virus was therefore investigated. Microscopic observations showed that USV disrupted normal cells within $3 \mathrm{~min}$. Infected cells were therefore treated for $4 \mathrm{~min}$. to ensure complete destruction of the cells and release of virus. To study the effect of USV on the infectivity of the released virus, the suspension was titrated and again treated with USV for $4 \mathrm{~min}$. There was no alteration in its infectivity (Table 1). There was a decrease, however, after more prolonged treatment. Three cycles of freezing in solid $\mathrm{CO}_{2}+$ ethanol followed by rapid thawing in a $37^{\circ}$ water bath caused a significant loss of infectivity (Table 1). Disruption by USV was therefore adopted as the method of choice.

Table 1. Effect of ultrasonic vibrations (USV) and three cycles of freezing and thazoing $(F \& T)$ on the infectivity of trachoma and inclusion blennorrhoea viruses in HeLa cell monolayers

\begin{tabular}{|c|c|c|c|c|}
\hline Virus & $\begin{array}{l}\text { Treatment } \\
\text { to release } \\
\text { virus from } \\
\text { cells }\end{array}$ & $\begin{array}{l}\text { No. IFU/ml. } \\
\text { suspension }\end{array}$ & $\begin{array}{l}\text { Treatment } \\
\text { of released } \\
\text { virus }\end{array}$ & $\begin{array}{l}\text { No. IFU/ml. } \\
\text { suspension }\end{array}$ \\
\hline Trachoma & $\begin{array}{c}\text { USV } \\
\text { USV } \\
\text { USV }\end{array}$ & $\begin{array}{r}8 \times 10^{3} \\
3 \times 10^{5} \\
9.5 \times 10^{4}\end{array}$ & $\begin{array}{l}\text { USV } \\
\text { USV } \\
\text { USV }\end{array}$ & $\begin{array}{l}7 \cdot 5 \times 10^{3} \\
1 \cdot 6 \times 10^{5} \\
1 \cdot 1 \times 10^{5}\end{array}$ \\
\hline Inclusion blennorrhoea & $\begin{array}{l}\text { USV } \\
\text { USV }\end{array}$ & $\begin{array}{l}7 \cdot 4 \times 10^{5} \\
5 \cdot 2 \times 10^{5}\end{array}$ & $\begin{array}{l}\text { USV } \\
\text { USV }\end{array}$ & $\begin{array}{l}6.5 \times 10^{5} \\
3.7 \times 10^{5}\end{array}$ \\
\hline Trachoma & $\begin{array}{l}F \& T \\
F \& T\end{array}$ & $\begin{array}{l}1.2 \times 10^{5} \\
4.4 \times 10^{4}\end{array}$ & $\begin{array}{l}F \& T \\
F \& T\end{array}$ & $\begin{array}{r}5 \times 10^{4} \\
8.4 \times 10^{3}\end{array}$ \\
\hline
\end{tabular}

Appearance of inclusions. To ascertain that all inclusions counted at time of assay were derived from virus in the original inoculum, monolayers were infected with a suitable dilution of virus and incubated; at $24 \mathrm{hr}$. intervals, four coverslips were selected at random, stained and examined. Although some inclusions could be seen after $24 \mathrm{hr}$., they were not readily identified until after $48 \mathrm{hr}$. when they were about the size of the cell nucleus. By $72 \mathrm{hr}$. the inclusions had enlarged, but had not significantly increased in number, indicating that a second cycle of infection had not occurred and that all the inclusions were derived from virus in the original inoculum. As a routine, therefore, results were read after 68-72 hr. since the inclusions were most easily counted at that time.

Random distribution of inclusions. An area of thirty consecutive fields along the length of the coverslip was arbitrarily chosen as the 'standard area' in which inclusions were counted. To determine whether the number of inclusions found in any one 'standard area' was a representative sample of the whole monolayer, several coverslips were picked at random and the inclusions in four different standard areas counted (a total of 120 different fields/monolayer). The number of inclusions found in each of the four standard areas was remarkably similar (Table 2). They seldom differed from the average for the 120 fields by more than $10 \%$. This suggested not only that an area of thirty fields was adequate for our purpose, but also that the inclusions were randomly distributed. Random distribution on any coverslip was confirmed by comparing the observed distribution of inclusions in each field with 
that expected from a Poisson series (Table 3) and testing the goodness of fit by the formula

$$
\chi^{2}=S\left\{\frac{(O-E)^{2}}{E}\right\},
$$

where $S$ implies summation, $O$ observed number and $E$ calculated number of inclusions/field. There was a reasonable fit.

Table 2. Variations in the number of inclusions counted in different areas of the same monolayer of HeLa cells

\begin{tabular}{lccccc} 
& \multicolumn{5}{c}{ Monolayer no.* } \\
\cline { 2 - 6 } Four 'standard areas' of 30 & 1 & 2 & 3 & 4 & 5 \\
consecutive fields & 124 & 133 & 135 & 138 & 309 \\
& 114 & 131 & 127 & 150 & 383 \\
Av. no./80 fields & 118 & 102 & 116 & 139 & 317 \\
& 134 & 129 & 116 & 136 & 367 \\
& 122.5 & 123.75 & 123.5 & $140 \cdot 75$ & 344
\end{tabular}

Difference between av. no.

in 30 fields and:

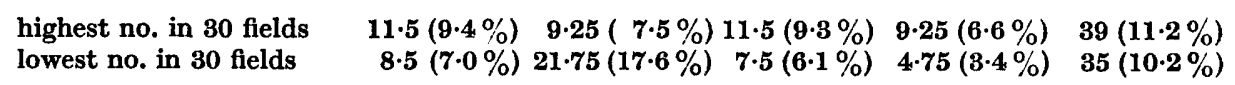

* Monolayers 1-4 inoculated with the same virus dilution.

Table 3. Poisson series fitted to inclusion counts

$\begin{array}{lrr}\quad \begin{array}{c}\text { No. of } \\ \text { inclusions/field }\end{array} & \overbrace{}^{\text {Obs. }} & \begin{array}{r}\text { Calc. } \\ 0-1\end{array} \\ 2 & 6 & 10 \cdot 2 \\ 3 & 17 & 18 \cdot 2 \\ 4 & 31 & 22 \cdot 9 \\ 5 & 20 & 23 \cdot 4 \\ 6 & 23 & 19 \cdot 2 \\ 7 & 12 & 12 \cdot 6 \\ 8 \text { and over } & 4 & 7 \cdot 5 \\ 9 \text { and over } & 7 & 6 \cdot 2 \\ \text { No. fields counted } & 120 & -120 \\ \text { Av. no. inclusions/ } & 4 \cdot 08 & \\ \text { field } & & \\ \text { Total no. inclusions } & 490 & \\ \text { counted } & \chi_{(6)}^{2} 7 \cdot 75 & \end{array}$

Monolayer no.

$\begin{array}{rrrrr}\text { Obs. } & \text { Obs. } & \text { Calc. } & \overbrace{\text { Obs. }} & \text { Calc. } \\ 8 & 4 & 9 \cdot 7 & 6 & 6 \cdot 2 \\ 14 & 17 & 16 \cdot 8 & 16 & 12 \cdot 1 \\ 23 & 26 & 22 \cdot 0 & 15 & 19 \cdot 1 \\ 31 & 31 & 23 \cdot 3 & 18 & 22 \cdot 3 \\ 17 & 20 & 19 \cdot 2 & 23 & 21 \cdot 0 \\ 16 & 11 & 13 \cdot 2 & 17 & 16 \cdot 4 \\ 6 & 7 & 7 \cdot 8 & 15 & 11 \cdot 0 \\ 5 & 4 & 6 \cdot 7 & 5 * & 6 \cdot 5 * \\ - & - & - & 5 & 4 \cdot 9 \\ 120 & 120 & 118 \cdot 7 & 120 & 119 \cdot 5 \\ 4.1 & 4.1 & & 4.7 & \end{array}$

* Eight inclusions only.

Optimum magnification for identifying inclusions. After incubation for $72 \mathrm{hr}$. inclusions can be recognized at magnifications of $\times 120$ and $\times 240$. The lower magnification gives a field 4 times larger than at $\times 240$, and its use might be advantageous when there are few infected cells. Counts made at both magnifications were, therefore, compared and were consistently lower at a magnification of $\times 120$ (Table 4). The higher magnification was therefore used as a routine. 
Variations between replicates. The accuracy of titrations, using respectively 3 and 4 replicate coverslips, was compared. These results, together with the \% standard deviation (\% s.D.) and \% standard error (\% s.E.) are given in Table 5. The standard deviation was calculated from the formula

$$
\text { S.D. }=\sqrt{\frac{S(x-\bar{x})^{2}}{N-1}},
$$

where $S$ implies summation, $x-\bar{x}$ is the difference of each replicate from the mean and $N$ the number of replicates; the \% standard error (\% s.E.) was calculated

Table 4. Variations in the number of inclusions seen in the same monolayer at $\times 120$ and $\times \mathbf{2 4 0}$ magnifications

\begin{tabular}{|c|c|c|c|}
\hline \multirow[b]{3}{*}{$\begin{array}{c}\text { Monolayer } \\
\text { no. }\end{array}$} & \multicolumn{3}{|c|}{ No. of inclusions in 30 fields at: } \\
\hline & \multicolumn{2}{|c|}{$\times 120$ magnification } & \multirow{2}{*}{$\begin{array}{c}\times \mathbf{2 4 0} \\
\text { magnification. } \\
\text { Inclusions } \\
\text { counted in } \\
\text { standard } \\
\text { area }\end{array}$} \\
\hline & $\begin{array}{l}\text { Inclusions } \\
\text { counted }\end{array}$ & $\begin{array}{c}\text { Counts } \\
\text { corrected to } \\
\text { standard area* }\end{array}$ & \\
\hline 6 & $\mathbf{3 4}$ & $8 \cdot 5$ & 11 \\
\hline 7 & 45 & $11 \cdot 25$ & 19 \\
\hline 8 & 92 & 23 & 30 \\
\hline 9 & 140 & 35 & 47 \\
\hline 10 & 142 & $35 \cdot 5$ & $\mathbf{5 1}$ \\
\hline 11 & 309 & $77 \cdot 25$ & 103 \\
\hline 12 & 317 & $79 \cdot 25$ & 120 \\
\hline 13 & 367 & $91 \cdot 75$ & 126 \\
\hline 14 & 383 & $95 \cdot 75$ & 141 \\
\hline
\end{tabular}

Table 5. Effect of the number of replicates on the $\%$ standard error (\% s.E.) and \% standard deviation (\% s.D.)

\begin{tabular}{|c|c|c|c|c|c|}
\hline \multicolumn{3}{|c|}{ Average of three replicates } & \multicolumn{3}{|c|}{ Average of four replicates } \\
\hline $\begin{array}{l}\text { Av./30 } \\
\text { fields }\end{array}$ & $\%$ s.D. & $\%$ s.E. & $\begin{array}{c}\text { Av. } / \mathbf{3 0} \\
\text { fields }\end{array}$ & $\%$ s.D. & \% s.e. \\
\hline 21 & 20 & $11 \cdot 6$ & 21 & $21 \cdot 9$ & 11 \\
\hline 43 & $16 \cdot 5$ & $9 \cdot 5$ & 44 & $17 \cdot 5$ & $\mathbf{8 \cdot 8}$ \\
\hline 47 & $18 \cdot 5$ & $10 \cdot 7$ & 46 & $16 \cdot 3$ & $8 \cdot 2$ \\
\hline 47 & 13 & $7 \cdot 5$ & 122 & $12 \cdot 9$ & $6 \cdot 5$ \\
\hline 66 & $\mathbf{3 6} \cdot 8$ & $21 \cdot 2$ & 167 & $16 \cdot 5$ & $32 \cdot 8$ \\
\hline 116 & $44 \cdot 8$ & $25 \cdot 9$ & 245 & $18 \cdot 0$ & $9 \cdot 0$ \\
\hline 121 & $15 \cdot 7$ & $9 \cdot 0$ & 454 & $17 \cdot 8$ & $9 \cdot 0$ \\
\hline 236 & $20 \cdot 8$ & $11 \cdot 4$ & & & \\
\hline 395 & $\mathbf{8 \cdot 3}$ & $4 \cdot 8$ & & & \\
\hline 399 & $28 \cdot 2$ & $16 \cdot 3$ & & & \\
\hline 417 & $42 \cdot 9$ & $24 \cdot 8$ & & & \\
\hline 471 & $19 \cdot 2$ & $11 \cdot 1$ & & & \\
\hline
\end{tabular}

as $\%$ S.D. $/ \sqrt{ } N$. As would be expected, increasing the number of replicates did not greatly improve the accuracy of the method. The \% s.F. was usually about $\pm 10 \%$, although it might be as high as $\pm \mathbf{2 5} \%$; errors which are due to the inevitable sampling variations. When the s.E. is outside these limits it appears preferable to repeat the assay rather than attempt to increase accuracy by using more replicates. 
These results indicated that within the limits tested (i.e. using four replicates, an average of 20-450 inclusions in 30 fields) the accuracy of the technique was not affected by the number of inclusions per field.

There was a linear relationship between concentration of virus and the inclusion count (Table 6).

Table 6. Relationship between inclusion count and virus concentration

$\begin{array}{cccc}\text { Virus } & \begin{array}{c}\text { Count } \\ \text { Dilution } \\ \text { factor }\end{array} & \begin{array}{c}\text { Av./30 } \\ \text { fields }\end{array} & \begin{array}{c}\text { Count } x \\ \text { dilution } \\ \text { factor }\end{array} \\ \text { Trachoma } & 10^{0} & 430 & 430 \\ & 10^{-1} & 61 & 610 \\ 10^{0} & 447 & 447 \\ 10^{-1} & 43 & 430 \\ 10^{0} & 395 & 395 \\ & 10^{-1} & 44 & 440 \\ & 10^{0} & 242 & 242 \\ & 10^{-0.5} & 81 & 256 \\ & 10^{-1} & 25 & 250 \\ & 10^{-0.5} & 269 & 850 \\ & 10^{-1} & 75 & 750 \\ 10^{-1.5} & 33 & 1040 \\ 10^{0} & 439 & 439 \\ & 10^{-1} & 40 & 400\end{array}$

\section{DISCUSSION}

Before a virus can be studied in detail a quantitative technique for its assay must be developed. The feline and murine pneumonitis viruses have been titrated by counting the inclusions formed in explants of yolk sac (Weiss \& Huang, 1954). Trachoma virus also induces lesions in such explants (Gordon, Quan \& Trimmer, 1960). However, the use of HeLa cells is much less laborious. When a standard area of 30 fields is counted in each of four replicate monolayers at $\times 240$ magnification, a standard error of approximately $\pm 10 \%$ may be expected; this compares favourably with the results obtained by Weiss \& Huang (1954). The slight increase in accuracy obtained by examining a greater proportion of the monolayer, or by using more replicates, does not offset the extra expenditure of time and materials.

Within the limits investigated, i.e. 20-450 inclusions in 30 fields, the same standard error may be expected. Thus each series of monolayers measures a relatively wide range of virus titre. However, only suspensions containing more than $7 \times 10^{3} \mathrm{IFU} / \mathrm{ml}$. can be assayed by the standard technique. To titrate lower concentrations, the size of the inoculum must be increased or a greater area of the monolayer examined. This cannot be achieved by using an optical system with a lower magnification and a correspondingly greater field area, as there is a significant decrease in the number of inclusions identified at the lower magnification.

We wish to thank Dr P. Armitage for his advice on statistics and Miss Margaret Ham for her excellent technical assistance. 


\section{REFERENCES}

Bovarnick, M. R., Miller, J. C. \& Snyder, J. C. (1950). The influence of certain salts, amino acids, sugars and proteins on the stability of Rickettsiae. J. Bact. 59, 509.

Collier, L. H., Duke-Erder, S. \& Jones, B. R. (1958). Experimental trachoma produced by cultured virus. Brit. J. Ophthal. 42, 705.

Furness, G., Graham, D. M., Reeve, P. \& Coliner, L. H. (1960). The growth of trachoma and inclusion blennorrhoea viruses in cell culture. Rev. int. Trachome. (in the Press).

Gordon, F. B., Quan, A. L. \& Trimmer, R. W. (1960). Morphologic observations on trachoma virus in cell cultures. Science, 131, 733 .

Jones, B. R., Collier, L. H. \& SMIth, C. H. (1959). Isolation of virus from inclusion blennorrhoea. Lancet, $\mathrm{i}, 902$.

Lwoff, A., Dulbecco, R., Vogt, M. \& Lwoff, M. (1955). Kinetics of the release of poliomyelitis virus from single cells. Virology, $1,128$.

'T'ang, F. F., Chang, H. L., Huang, Y. T. \& Wang, K. C. (1957). Studies on the etiology of trachoma with special reference to isolation of the virus in chick embryo. Chin. med. J. 75, 429.

Weiss, E. \& Huang, J. S. (1954). The infected cell count method of titration of feline pneumonitis virus. J. infect. Dis. 94, 107. 